\title{
Origin of the Myklegardfjellet Bed, a basal Cretaceous marker on Spitsbergen
}

\author{
HENNING DYPVIK, JENØ NAGY AND DAVE H. KRINSLEY
}

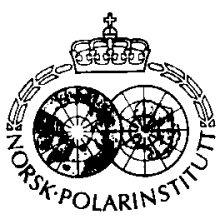

Dypvik, H., Nagy, J. \& Krinsley, D. H. 1992: Origin of the Myklegardfjellet Bed, a basal Cretaceous marker on Spitsbergen. Polar Research 11(1), 21-31.

The Ryazanian Myklegardfjellet Bed, composed of yellow to greenish plastic clays, is a regional marker horizon in central and eastern Spitsbergen, where it occurs just above the boundary between the Agardhfjellet and Rurikfjellet formations. Through a combined mineralogical, sedimentological and micropaleontological approach, it is demonstrated that the bed was deposited by marine shelf processes and subsequently altered by decomposition of the unstable glauconite bearing components. These sediments were deposited at the culmination of a shallowing episode in the depositional area. This event marks a shift in depositional mode, from predominantly shelf sedimentation controlled by global eustatic sea level changes (Late Bathonian-Ryazanian), to a locally regulated, deep sea to shallow shelf-prodeltaic to deltaic pattern of deposition (Ryazanian-Hauterivian).

H. Dypuik and J. Nagy, Department of Geology, University of Oslo, P.O. Box 1047 Blindern, N-0316 Oslo, Norway; D.H. Krinsley, Department of Geological Sciences, University of Oregon, Eugene, Oregon 97403-1272, USA.

\section{Introduction}

The shale- and siltstone-dominated Janusfjellet Subgroup in central and eastern Spitsbergen is generally about $400 \mathrm{~m}$ thick and is made up of shelf and prodeltaic deposits. The subgroup is divided into the Bathonian-Ryazanian (Boreal Berriasian) Agardhfjellet Formation and the Ryazanian-Hauterivian Rurikfjellet Formation (Figs. 1 and 2). Whereas the Agardhfjellet Formation consists of dark paper shales and sand/silt-ridge deposits of mid to outer shelf affinity, the grey shales, silt- and sandstones of the Rurikfjellet Formation represent outer shelf to inner shelf, prodeltaic depositional conditions (Dypvik et al. 1991a, b).

The transition between the two formations is marked by a $0.5 \mathrm{~m}$ to roughly $10 \mathrm{~m}$ thick unit which in surface exposures is dominated by yellow to greenish plastic clay layers. The individual layers are commonly coated by iron oxides and jarosite. No information is published about the subsurface attributes of the bed. This marker horizon has been found everywhere in central and eastern Spitsbergen (Fig. 1) where the transition between the Agardhfjellet and Rurikfjellet formations is exposed. To date, it has not been observed along the western coast (W. Dallmann pers. comm. 1991). This thin but distinctive unit was originally named the Myklegardfjellet Bed by Birkenmajer (1980) with type locality at Agardhbukta, and it is referred to the base of the Rurikfjellet Formation (Fig. 2).

\section{Materials and methods}

The field work forming the basis of this study was carried out in 1986 and 1987 when a large number of localities were investigated in central Spitsbergen. Detailed analyses of the Myklegardfjellet Bed are presented herein from the well-exposed locality at Glitrefjellet, in the inner part of Reindalen (Fig. 1).

In the laboratory the clay samples were dried, crushed to rock powder and analysed using a Philips X-ray diffractometer; both bulk and claymineralogical analyses were carried out. The analyses were run according to the standard methods of Brindley \& Brown (1980); the results are presented in Tables 1 and 2 .

Shale cubes, approximately $2 \mathrm{~cm}^{3}$, were prepared and embedded completely in epoxy, which was cured at room temperature for 24 hours. The 


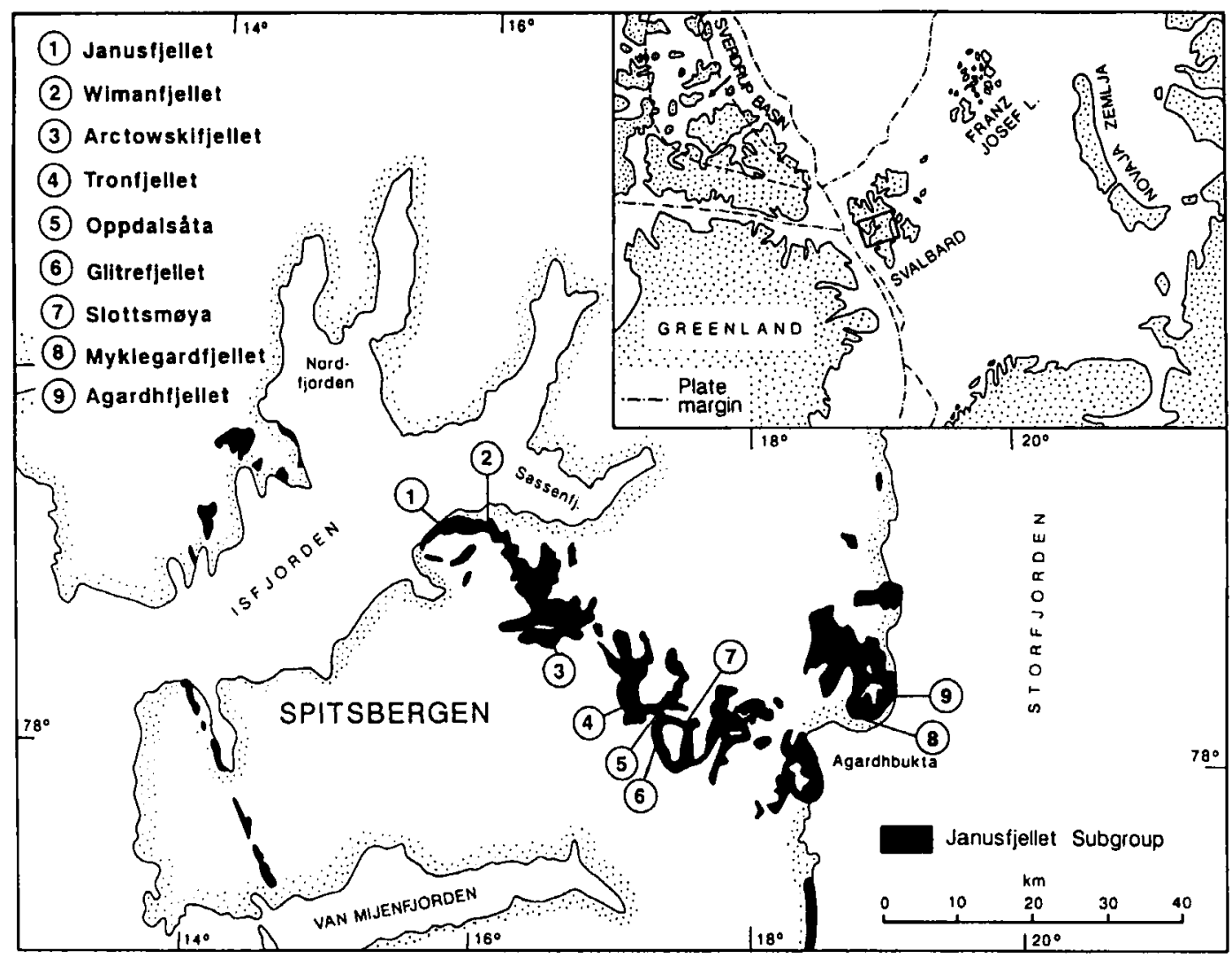

Fig. 1. Map of central Spitsbergen showing outcrops of the Janusfjellet Subgroup and some important localities of the Myklegardfjellet Bed. Inset map: Mesozoic position of Svalbard (area covered by main map boxed).

specimens were then ground on glass laps with increasingly finer grinding powders, finishing with a 1 micron diamond paste. Finally, the samples were coated with carbon in a vacuum evaporator and examined with a scanning electron microscope (ISI SS40) in the secondary and backscattered modes.

For the foraminiferal analysis, shale samples were disintegrated in accordance with the socalled "kerosene method" (Nagy et al. 1988). The dry shale $(80-100 \mathrm{~g})$ was soaked in kerosene for about 30 minutes. After decanting the kerosene, the sediment was boiled in a sodium hydroxide solution for 15 minutes or more, depending on the degree of consolidation. The plastic clay samples were disintegrated by boiling in water with detergent. For the foraminiferal analyses, the $>0.125 \mathrm{~mm}$ fraction was used.

\section{Lithology and fauna of the Myklegardfellet Bed}

\section{Field occurrence}

The Myklegardfjellet Bed is a soft, yellow to greenish clay unit with thicknesses of roughly 0.5 to $10 \mathrm{~m}$. On the northern slope of Arctowskifjellet (Figs. 1 and 3), the bed is up to $2 \mathrm{~m}$ thick and contains a lower $(15 \mathrm{~cm})$ and an upper $(30 \mathrm{~cm})$ clay layer separated by grey shales (Fig. 4). The two layers are made up of 5 to $10 \mathrm{~cm}$ thick plastic clay intervals with yellow/reddish to grey colours, separated by grey clay.

At Lardyfjellet, the bed is a $40 \mathrm{~cm}$ thick unit consisting of white, yellow and green clays, mainly reflecting various stages of secondary iron oxidation. Scattered coarse sand grains of glau- 


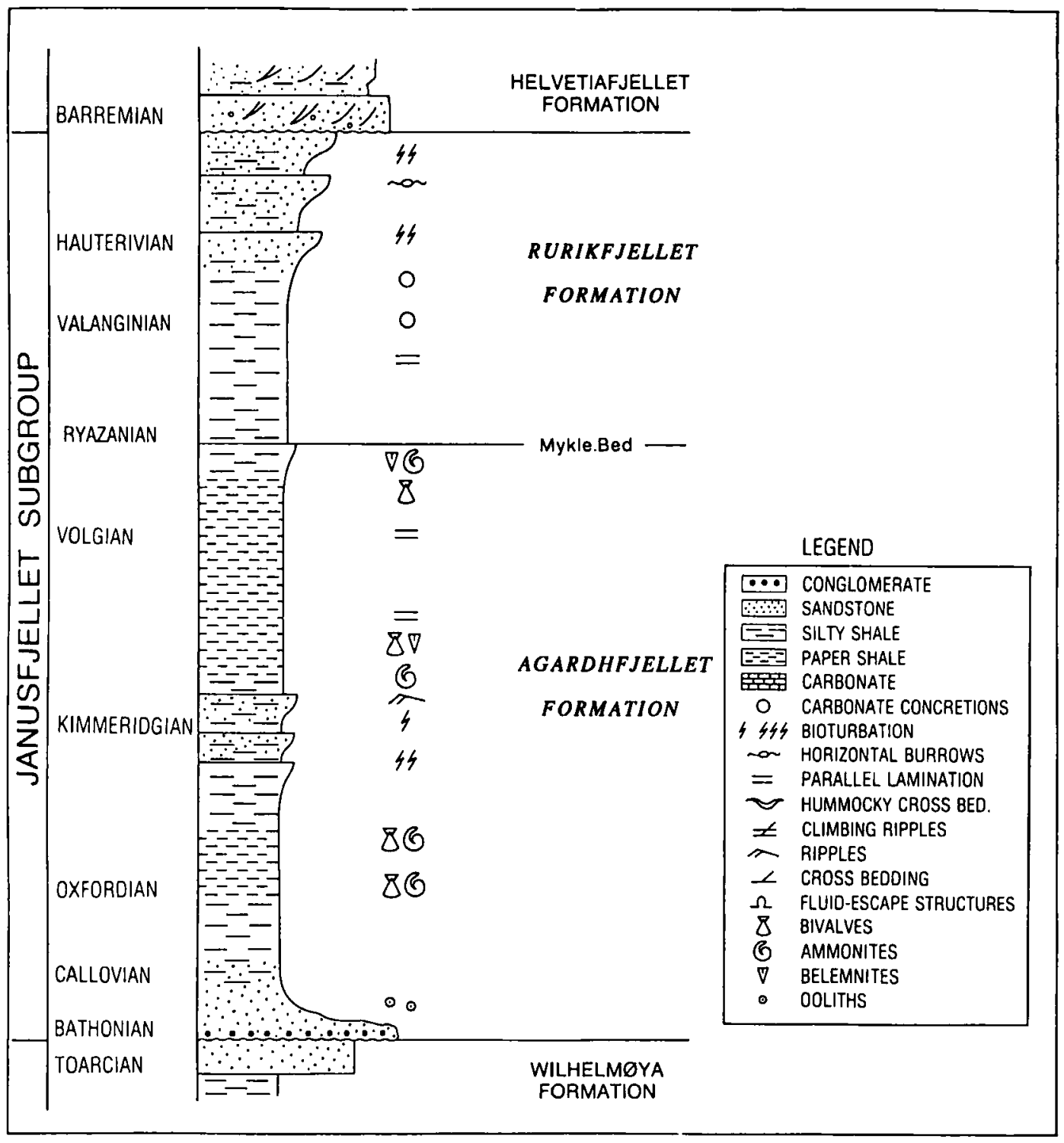

Fig. 2. Generalised stratigraphy of the Janusfjellet Subgroup.

Table 1. X-ray diffraction results of bulk analyses of samples from Glitrefjellet. The measurements have been quantified according to Brindley \& Brown (1980), and consequently the results are only semiquantitative. Values are in per cent. Position of samples shown in Fig. 6.

\begin{tabular}{llllllllll}
\hline Sample & Chlorite & Smectite/llite & Illite & Kaolinite & Gypsum & Quartz & K-feldspar & Plagioclase & Jarosite \\
\hline 100 & - & 6 & 6 & 3 & 6 & 32 & 8 & 11 & 28 \\
101 & + & 6 & 6 & 4 & 5 & 35 & + & 10 & 34 \\
102 & - & 4 & 3 & 1 & 9 & 32 & + & 9 & 42 \\
103 & - & 6 & + & - & 4 & 34 & - & 9 & 47 \\
104 & + & 5 & 6 & 4 & 8 & 44 & + & + & 33 \\
105 & 3 & + & 12 & 9 & - & 55 & 8 & 13 & - \\
\hline
\end{tabular}


Table 2. Clay mineralogy of samples trom the Glitrefjellet section. Fraction $(2 \mu \mathrm{m})$ is separated out after gently crushing the samples. Since the crushing may be of varying degrees, and the analyses were semiquantitative, the results are only approximate. Values are given in per cent. Position of samples shown in Fig. 6.

\begin{tabular}{lllll}
\hline Sample & Chlorite & Smec./llite & Illite & Kaolinite \\
\hline 100 & 0 & 36 & 30 & 34 \\
101 & 0 & 30 & 40 & 30 \\
102 & 0 & 48 & 33 & 19 \\
103 & 0 & 45 & 27 & 28 \\
104 & 0 & 38 & 29 & 33 \\
105 & 18 & 24 & 23 & 35 \\
\hline
\end{tabular}

conite have been observed. The reddish brown colours seen along the lower and upper contacts with the clay beds indicate more extensive oxidation along the boundaries.
At Glitrefjellet (Figs. 5 and 6), the Myklegardfjellet Bed appears as a $50 \mathrm{~cm}$ thick interval of plastic, yellowish to light grey clays. Glauconite occurs in varying amounts. Enrichments of glauconite are observed also at other localities, e.g. at Tronfjellet. There, $70 \mathrm{~cm}$ of glauconitic, silty clays and siltstones, containing two $10 \mathrm{~cm}$ thick plastic clay layers, are observed. At both Oppdalsåta and Slottsmøya, grey to yellow and green plastic clays make up the Myklegardfjellet Bed. Belemnites have been found in this bed at Glitrefjellet and Arctowskifjellet.

\section{Foraminiferal content}

In accordance with its marine origin, the Myklegardfjellet Bed contains foraminiferal tests at each locality analysed for this microfossil group. Foraminiferal analyses have been carried out on samples from Arctowskifjellet, Janusfjellet,

\section{ARCTOWSKIFJELLET SECTION MYKLEGARDFJELLET BED}

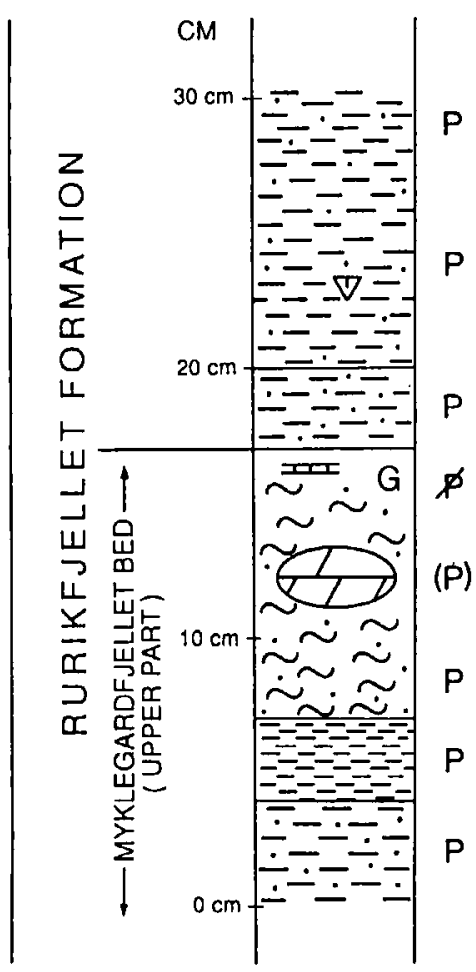

\section{LEGEND:}

$\because \because$ SAND
$\because$ SILT
CLAYSTONEI
SHALE
SOFT, YELLOW
CLAY CARBONATE
CARBONATE
G GLNCRETION

P PLASTIC

(P) PARTLY PLASTIC

\ NON PLASTIC

$\nabla$ BELEMNITE

8 BUCHIA

$\zeta$ BIOTURBATION

$\Varangle$ NO BIOTURBATION

Fig. 4. Log of the Myklegardfjellet Bed at Arctowskifjellet. 
Origin of the Myklegardfjellet Bed 25

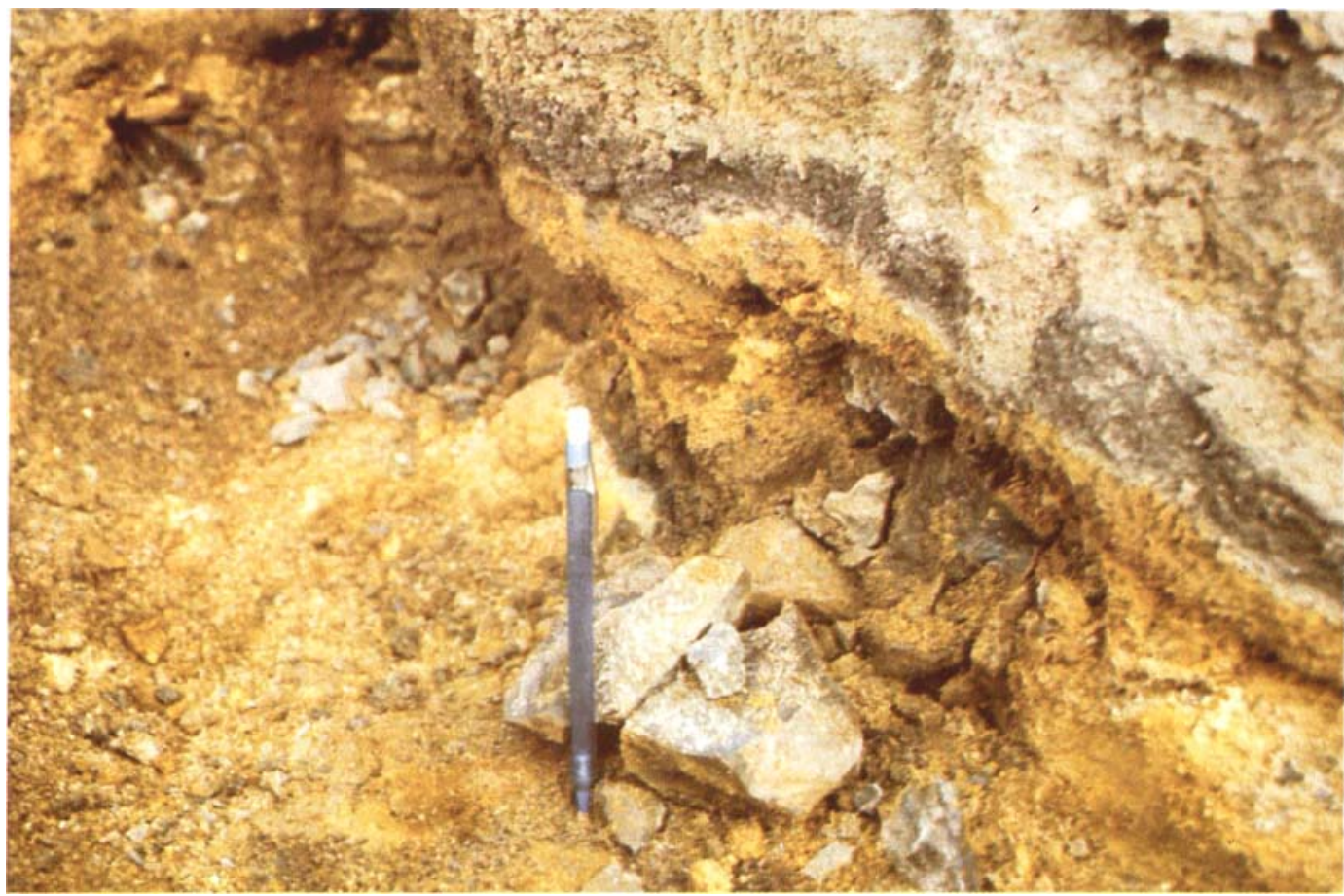

Fig. 3. Photo of the Myklegardfjellet Bed at Arctowskifjellet.

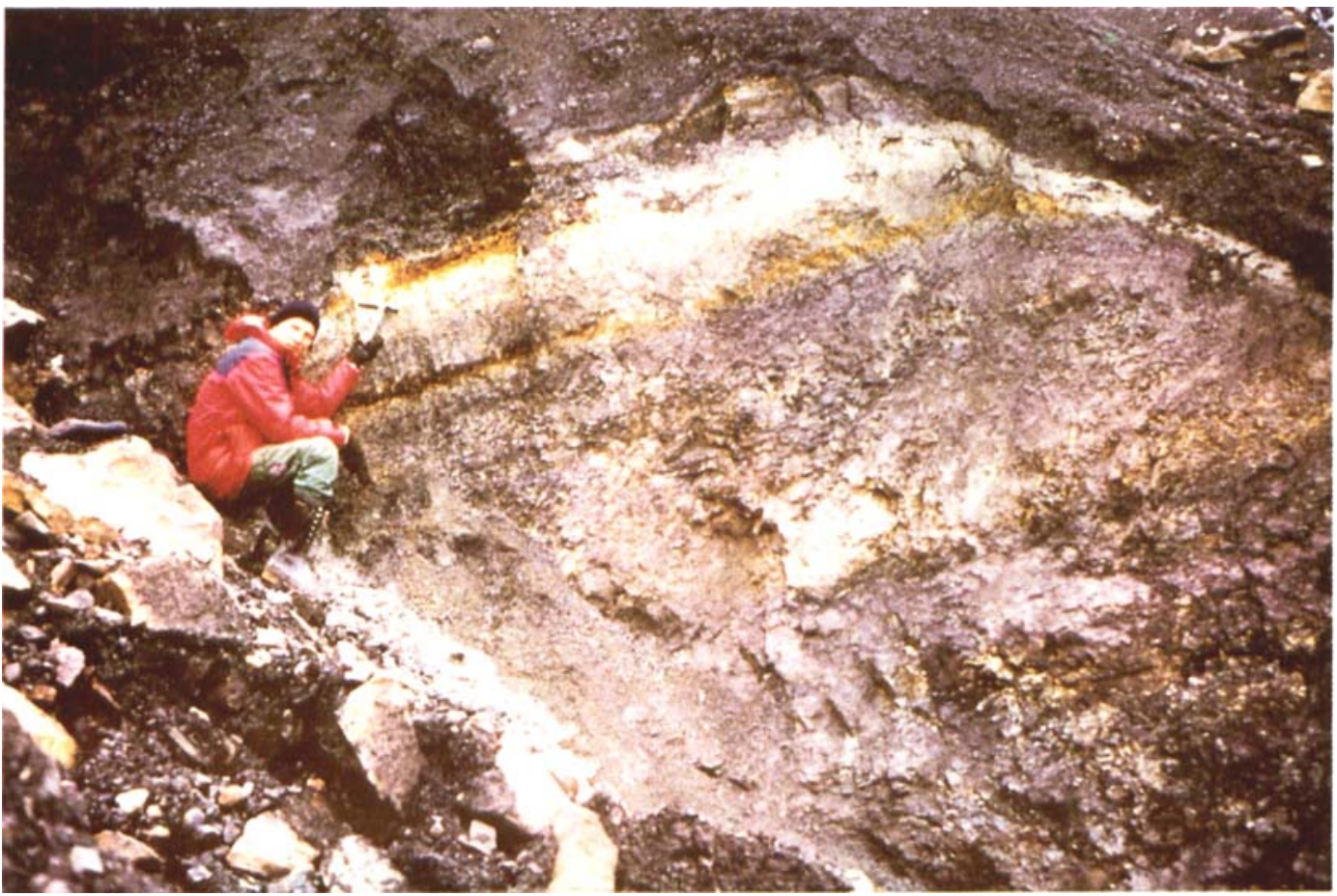

Fig. 5. Photo of the Myklegardfjellet Bed at Glitrefjellet. 


\section{GLITREFJELLET SECTION MYKLEGARDFJELLET BED}

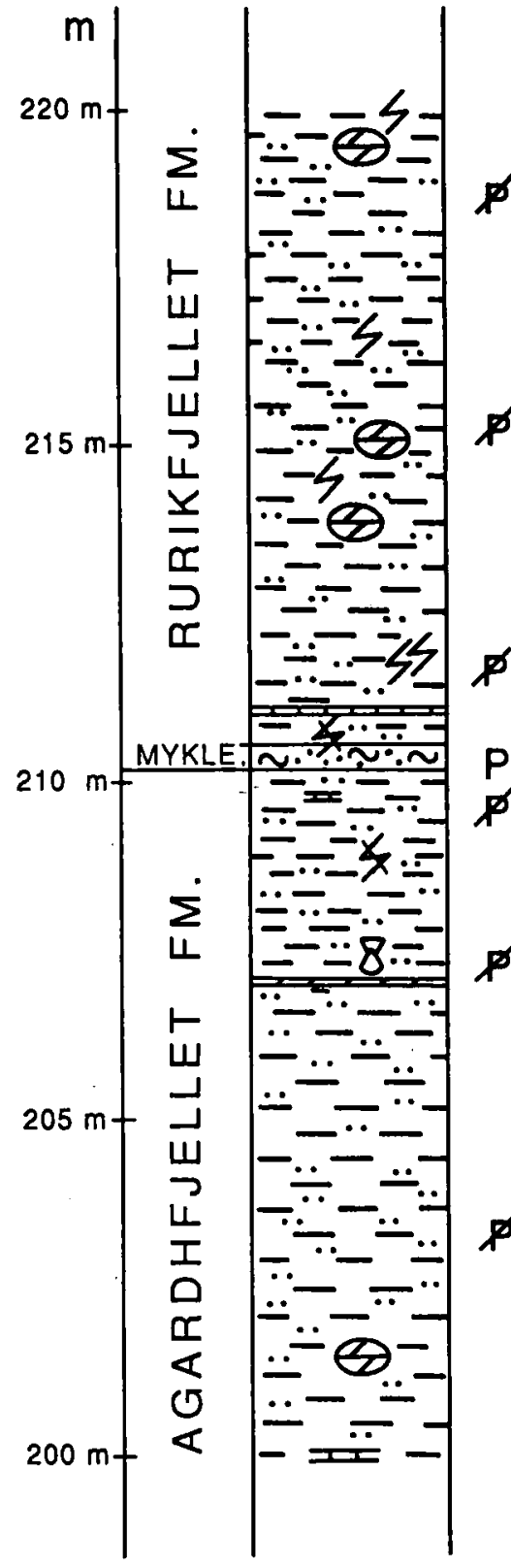

Oppdalsăta and Agardhfjellet (Fig. 1). A recent study of the foraminiferal faunas from the latter three localities (Nagy et al. 1990b) has shown that the assemblages of the Myklegardfjellet Bed
Fig. 6. Log of the Myklegardfjellet Bed and surrounding strata at Glitrefjellet.

compose mainly a single faunal unit, the Gaudryina aff. milleri Zone, which forms a thin, but regionally persistent horizon.

The foraminiferal faunas of the Janusfjellet 
Subgroup generally consist of agglutinating species. Calcareous foraminifera normally occur very sporadically, and quantitatively significant amounts are recorded only from the Myklegardfjellet Bed and the upper half of the Rurikfjellet Formation in the Agardhfjellet section (Nagy et al. 1988). The Myklegardfjellet Bed in that section contains up to 18 foraminiferal species, which represent the maximum species diversity in the section. The amount of calcareous species has its maximum in this bed as well, reaching $25 \%$ of the fauna. At the localities to the northwest, the calcareous faunal component is strongly diminished and consists only of a few specimens, as seen in the Oppdalsăta and Janusfjellet sections. However, at these localities, too, the species diversity in the Myklegardfjellet Bed varies significantly; it attains maximum values in certain horizons, but is sharply reduced in others.

The foraminiferal assemblages in the Myklegardfjellet Bed typically exhibit large vertical compositional changes, as demonstrated in both the Janusfjellet, Arctowskifjellet (Fig. 7) and Agardhfjellet sections. These changes are expressed by replacement of relatively high diversity faunas by faunas of extremely low diversity, consisting almost exclusively of a single species, e.g. Haplophragmoides sp. 2 (Nagy et al. 1990b) or Recurvoides obskiensis Romanova.

\section{Textural composition}

Six samples from the Glitrefjellet section were studied in great detail in the SEM/BSE analyses (Figs. 6, 8 and 9). The samples are enriched in glauconite, with the grains commonly floating in a feathery-appearing matrix of possible illite/ smectite clay minerals. The matrix is rich in iron, probably representing altered original glauconite. The sample texture is generally irregular with a disordered clay-rich matrix between grains of authigenic glauconite and clastic quartz and feldspars.

Samples from the middle part of the Myklegardfjellet Bed at Glitrefjellet are especially rich in glauconite; however, they display broad grainsize variations. The glauconite grains are mainly angular in shape, with sharp boundaries in contact with surrounding pyrite and matrix. Diagenetically formed pyrite is commonly observed around and along fractures within the glauconite grains.

The two samples analysed from the grey shales immediately below and above the Myklegardfjellet Bed (numbers 100 and 105 in Fig. 6, respect-

Arctowskifjellet

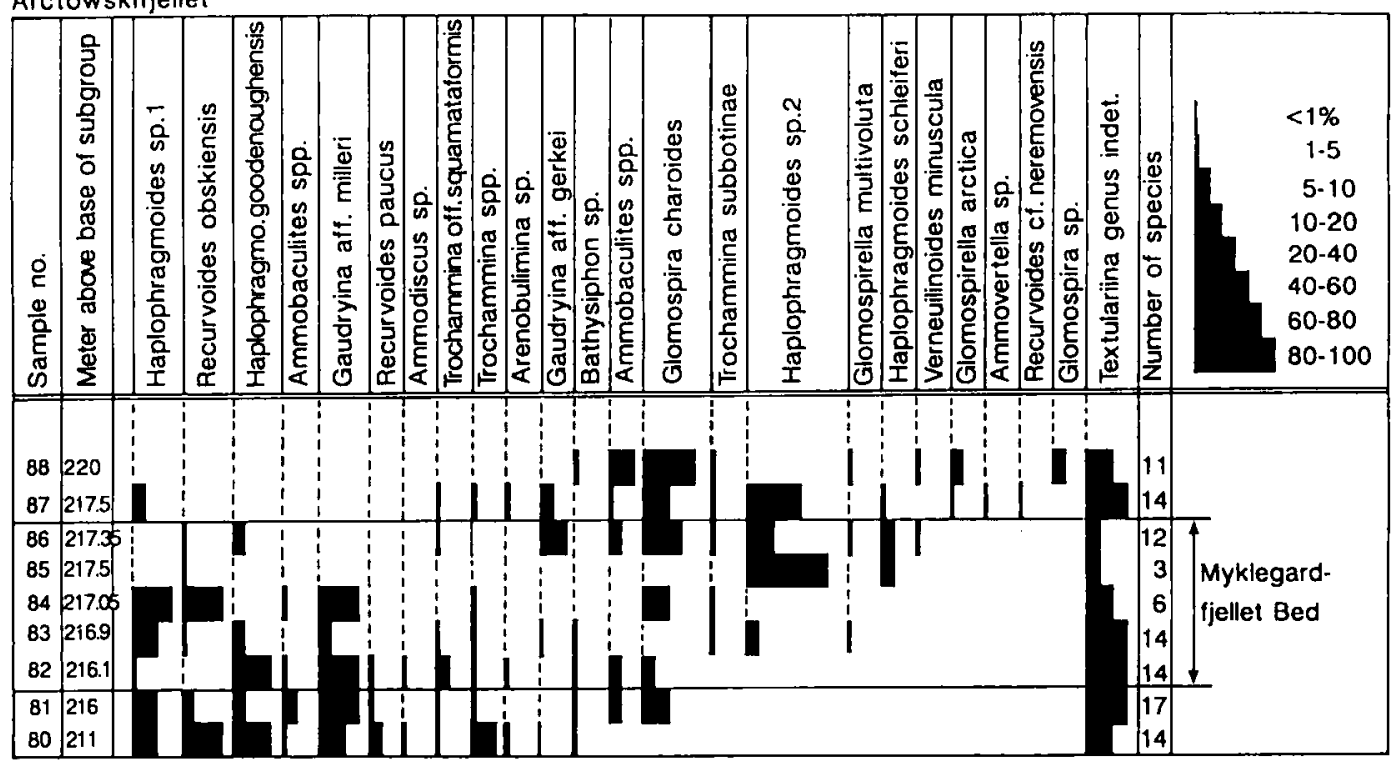

Fig. 7. Distribution of foraminiferal species in the Myklegardfjellet Bed at Arctowskifjellet. 
28 Henning Dypvik, Jenф Nagy \& Dave H. Krinsley
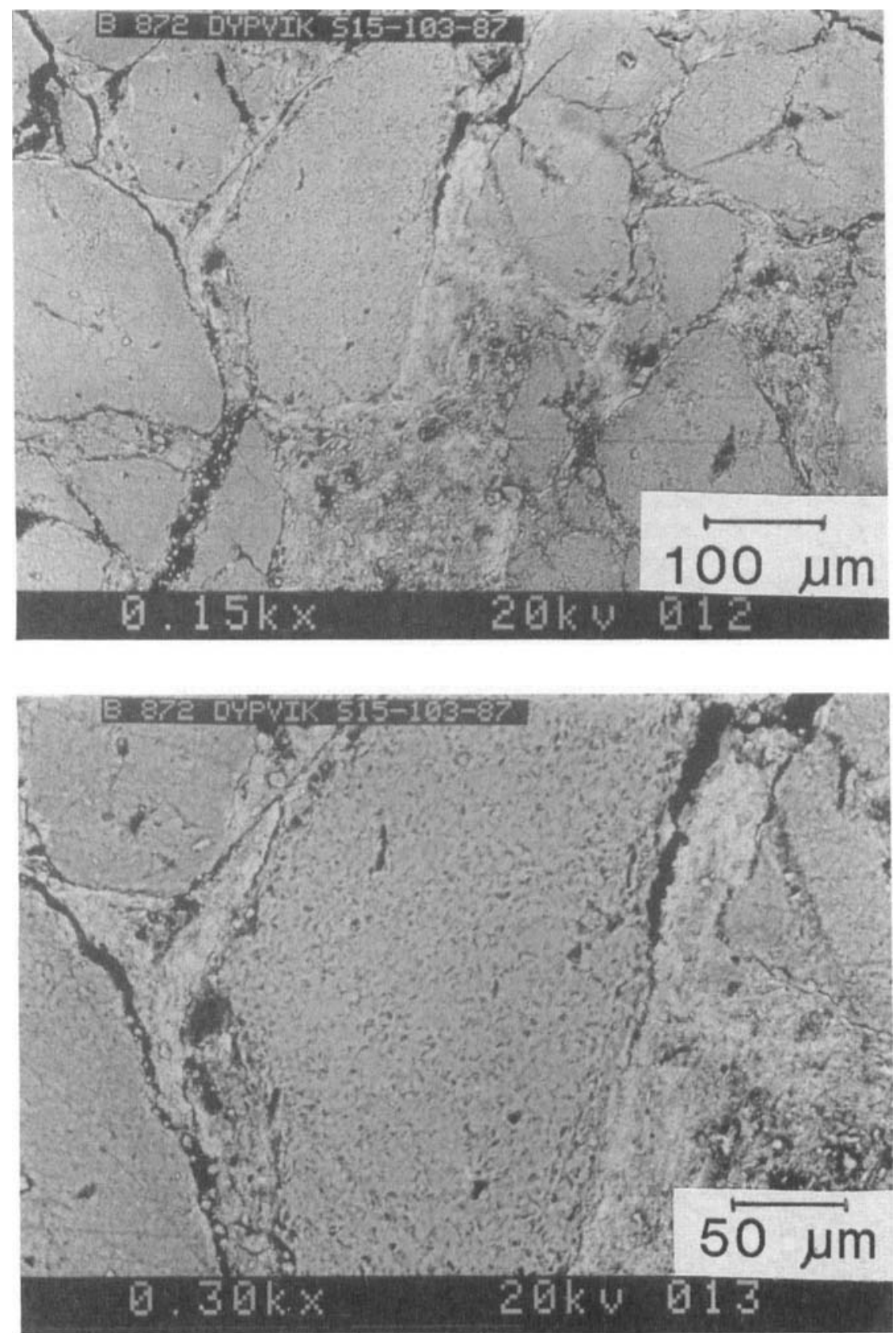

Fig. 8. Micrographs of SEM/BSE from the Myklegardfjellet Bed at Glitrefjellet. The glauconitic grains are angular in shape and appear unsorted in texture.

ively) contain hardly any glauconite. These samples also display faint parallel lamination, in contrast to the structureless appearance of the Myklegardfjellet Bed.
Bulk mineralogical analysis of samples from Glitrefjellet shows the sediment to be composed of illite/smectite mixed layered clay minerals, quartz, feldspar (both potash and plagioclase) and 

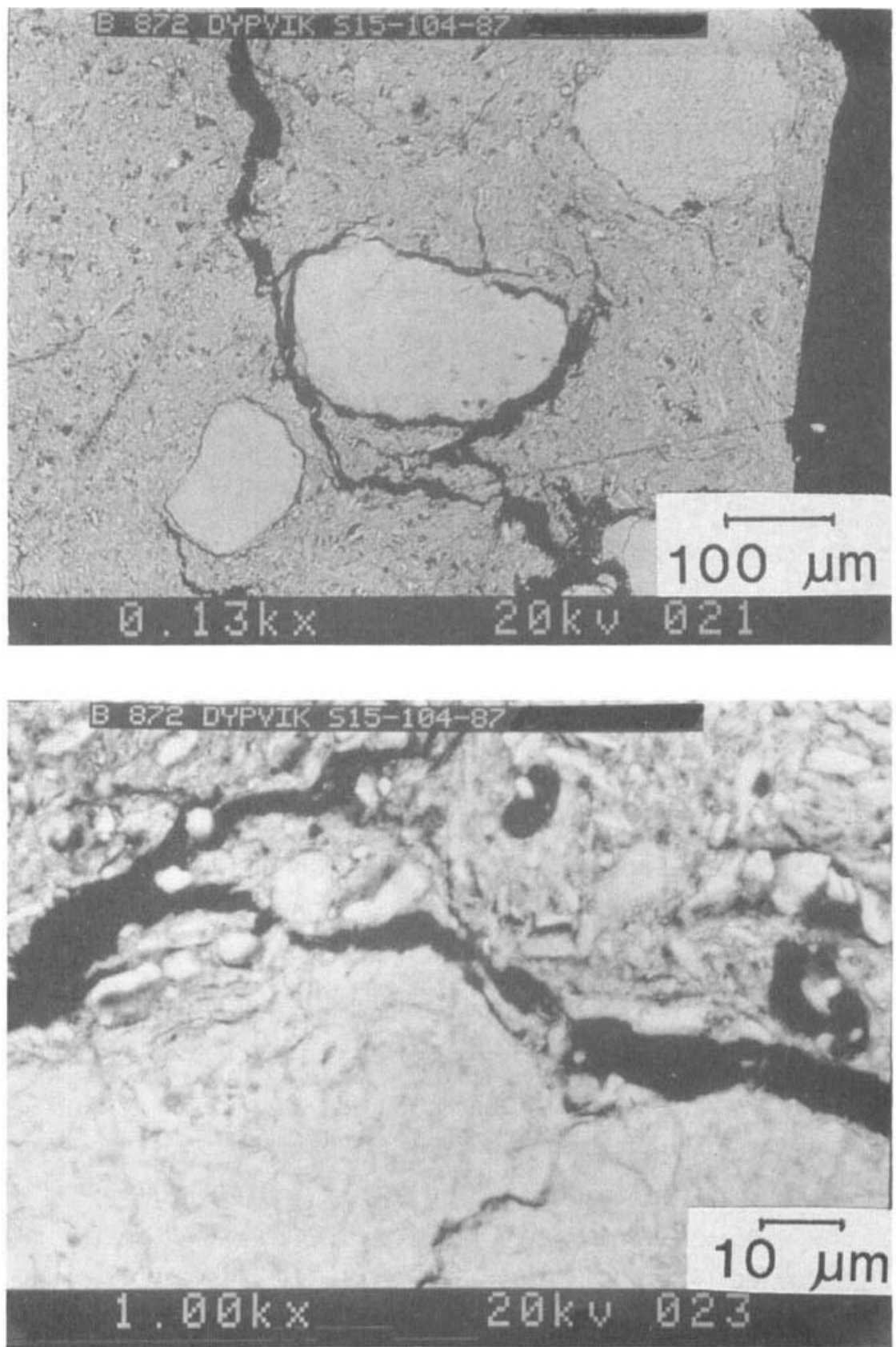

Fig. 9. Micrographs of SEM/BSE from the Myklegardfjellet Bed at Glitrefjellet, showing feathery-looking clay minerals.

secondary weathering products such as gypsum and jarosite (Table 1). The large amounts of secondarily formed weathering minerals reflect high degrees of alteration, underlining the dif- ficulties in interpreting the origin and formation of the Myklegardfjellet Bed.

The clay mineralogical composition of the samples seems complex at first glance, due mainly 
to large amounts of iron oxides, jarosite and also some gypsum, covering the clay minerals and hampering the diffraction signals. More detailed analyses of the clay fraction shows, however, that this is made up of iron-rich illite/smectite mixed layered clay minerals, illite and some kaolinite (Table 2). The SEM/BSE study and the elemental point analyses demonstrate that the iron-rich mixed layered clay minerals represent altered glauconite (Figs. 8 and 9). The presence of glauconite may also be reflected by the main elemental composition, which includes high enrichments of $\mathrm{Fe}, \mathrm{Mg}$ and $\mathrm{K}$.

\section{Stratigraphical significance of the Myklegardfjellet Bed}

\section{Regional extension and formation}

The Myklegardfjellet Bed has been observed throughout central and eastern Spitsbergen. Its extensive distribution and unusual lithology resulted in earlier discussions suggesting a possible bentonite or tuff related origin (Birkenmajer 1980). Parker (1967) suggested that the yellow clays of the Agardhbukta area might represent weathered dolerites, a possibility also discussed by Birkenmajer (1980).

The present study, however, demonstrates a dominantly glauconitic composition for most of the grains. The matrix consists mainly of mixed layered clay minerals, most likely derived from the alteration of originally glauconitic material. This alteration may be of sub-recent/recent origin and the result of rapid weathering of unstable, glauconitic sediments.

The glauconite-rich component of the Myklegardfjellet Bed commonly appears as unsorted angular grains, showing local grain derivation of the glauconite and possibly some local reworking. The large regional extension of the bed, along with its persistent glauconitic composition, clearly demonstrate its stratigraphic importance as a marker bed of possible cyclical/sequential significance. Laursen (1991) recently discussed the Myklegardfjellet Bed as part of a maximum flooding surface which could be correlated to exploration wells in the Barents Sea. Århus et al. (1990) describe glauconitic, condensed Valan- ginian beds from the Barents Sea, south of Bjørnøya (Bear Island), which might belong to the same depositional episode as the Myklegardfjellet Bed. The carbonate dominated Tordenskjoldberget Member (basal Cretaceous) in Kong Karls Land is probably also a lateral environmental equivalent of the Myklegardfjellet Bed.

\section{Age relationships}

The foraminiferal assemblages occurring in the Myklegardfjellet Bed show an obvious similarity to Siberian faunas of Ryazanian age and are referred to this stage. The stratigraphically most significant species of the bed, and their occurrences in Siberia, are as follows (on the basis of Bulynnikova 1967, Sharovskaya 1968, Dain 1972, and Saks 1972): Recurvoides obskiensis Romanova, uppermost Volgian to Lower Hauterivian; Recurvoides paucus Dubrovskaya, Ryazanian to Lower Hautervian; Haplophragmoides schleiferi Sharovskaya, Volgian to Ryazanian; Lenticulina sossipatrovae Gerke and Ivanova, Ryazanian to Lower Valanginian, rare in Volgian.

The foraminiferal assemblages occurring immediately below the Myklegardfjellet Bed are characterised by Recurvoides obskiensis and contain both Volgian and Ryazanian faunal components. The foraminiferal assemblage developed immediately above the Myklegardfjellet Bed is typified by Glomospirella multivoluta (Romanova). In western Siberia, this species occurs in Valanginian deposits according to Romanova (in Glazunova et al. 1960). Thus, the foraminiferal assemblages of the Myklegardfjellet Bed and of the adjacent strata suggest that the bed belongs to the Ryazanian.

\section{Depositional shift in the Ryazanian}

The deposition of the Agardhfjellet Formation was initiated by a transgression in the Late Bathonian. The inundated area of Spitsbergen had mainly dysaerobic to anaerobic bottom conditions in the Oxfordian and Kimmeridgian. These stagnant conditions are expressed by the formation of organic-rich paper shales containing low diversity agglutinated foraminiferal assemblages and locally unfossiliferous zones (Fig. 10).

In central Spitsbergen, the upper half of the Agardhfjellet Formation shows an upwards decreasing TOC content and an upwards increas- 


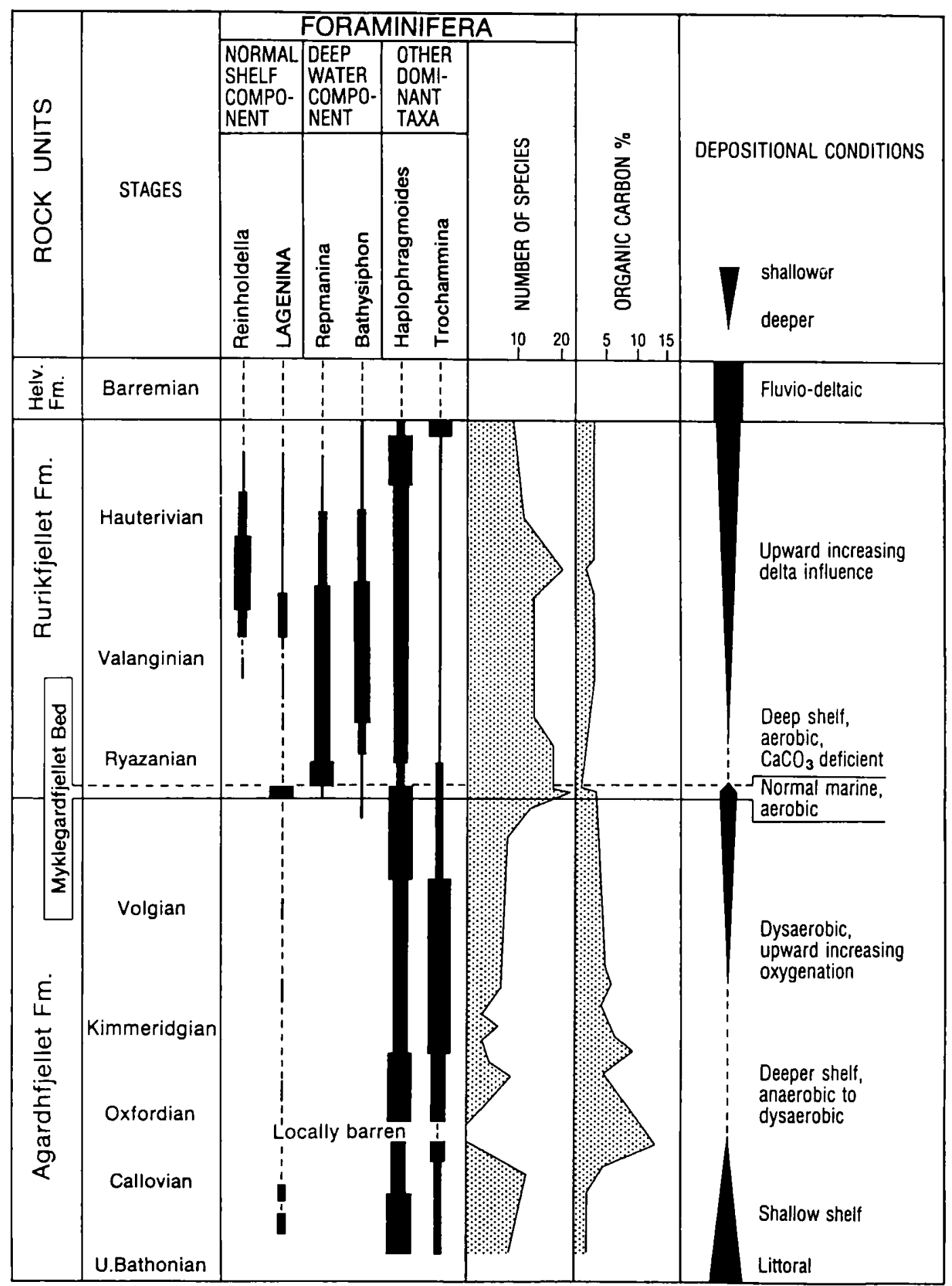

Fig. 10. The Myklegardfjellet Bed marking the transition between partly stagnant shelf regime (the Agardhfjellet Formation) and delta-influenced shelf regime (the Rurikfjellet Formation). Modified after Nagy et al. (1988). 
ing foraminiferal species diversity (Nagy et al. 1988). These features were apparently connected with increasing oxygenation of the water masses, caused by a shallowing episode of the depositional area. This shallowing culminated in the deposition of the Myklegardfjellet Bed, as expressed by the establishment of aerobic, locally almost normal marine conditions. These conditions are reflected by comparatively high species diversities at certain levels and locally significant quantities of calcareous foraminifera (Lagenids), which are regarded as a normal marine shelf component (Nagy et al. 1990a).

The depositional environment was quite unstable during the formation of the Myklegardfjellet Bed as indicated by the following:

1. Foraminiferal assemblages of comparatively high diversity developed during periods of improved marine conditions. Under optimal conditions these assemblages contained a significant calcareous component (e.g. in the Agardhfjellet section, Fig. 10).

2. Almost monospecific assemblages which probably represent pioneering faunas that recolonised the sea bed after periods which were unhospitable for foraminifera. The shallow shelf conditions of ventilated waters and a reduced terrigenous clastic supply were followed by a marked increase of water depth in the depositional area. At this stage, represented by the lower part of the Rurikfjellet Formation, clays characterised by low amounts of organic matter were deposited under stable, aerobic conditions (Fig. 10). The increase in water depth is reflected by the development of a new foraminiferal fauna, showing intermediate species diversities, almost total absence of calcareous foraminifera, and common occurrence of the genera Repmanina and Bathysiphon, both commonly assumed to be associated with deep water conditions. The total absence of calcareous foraminifera at the beginning of this phase suggests reduced availability of calcium carbonate.

Upwards in the Rurikfjellet Formation there is a reduction of the deep water faunal component, and the intermittently developed shelf component is also diminished in the upper part of the formation. These changes are attributed to upwards increasing deltaic influence and gradual shallowing of the depositional basin, finally succeeded by deltaic progradation terminated by fluvial sedimentation.

\section{Conclusions}

Extensive field work has shown that the Ryazanian Myklegardfjellet Bed is an important marker horizon which occurs throughout central and eastern Spitsbergen. The origin of the bed was investigated by a combined petrographical and micropaleontological approach. We conclude that the bed was originally deposited under marine shelf conditions, and subsequently altered by decomposition of its unstable, glauconitic components. This interpretation is supported by the locally rich occurrence of glauconitic grains, which are dispersed in a matrix of mixed layered clay minerals most likely derived from altered glauconitic material.

The Myklegardfjellet Bed marks the transition between two regionally dominant depositional regimes:

1. Mainly globally controlled, shallow marine cyclical shelf sedimentation during Middle Jurassic to earliest Cretaceous time, resulting in the deposition of the Agardhfjellet Formation (Dypvik 1992).

2. Locally and tectonically regulated regressive sedimentation of mainly prodeltaic to delta front affinity in the Early Cretaceous, leading to deposition of the Rurikfjellet Formation (Dypvik et al., 1991b).

This regional shift in depositional mode is typically expressed by reduced clastic supply associated with condensed chemical sedimentation, in possible combination with a maximum flooding event. Repeated short episodes of shelf reworking and breaking up of glauconite grains finally (at the beginning of Rurikfjellet time) resulted in the deposition of the Myklegardfjellet Bed.

Acknowledgements. - The project was supported financially by BP Petroleum Development (Norway) Ltd. (R\&D 1068). The comments of A. Dale (University of Oslo), A. Mørk and N. Århus (IKU, Trondheim) and two referees are highly appreciated.

\section{References}

Birkenmajer, K. 1980: Jurassic-Lower Cretaceous succession at Agardhbukta, East Spitsbergen. Studia Geologica Polonica 66, 35-52.

Brindley, G. W. \& Brown, G. 1980: Crystal structures of clay minerals and their X-ray identification. Mineralogical Society Monograph 5. 495 pp.

Bulynnikova, S. P. 1967: Some Litudids from Valanginian and Hauterivian deposits of the west-Siberian lowland. Pp. 57-67 
in Mesozoic and Cenozoic foraminifera of Western Siberia, Taymir and the Far East. Institut Geologii i Geofiziki, Sibirskoje Otdelenie, Akademija Nauk SSSR 12 (Russian).

Dain, L. G. (ed.) 1972: Foraminifera of Upper Jurassic deposits of western Siberia. Trudy Vsesajuznovo Neftjanovo Nauchnoissledovatelskovo Geologorazvedoknovo Instituta (VNIGRI) 317, 1-272 (Russian).

Dypvik, H. 1992: Sedimentary rythms in the Jurassic Cretaceous of Svalbard. Geological Magazine 129 (1), 93-99.

Dypvik, H., Nagy, J., Eikeland, T. A., Backer-Owe, K., Andresen, A., Haremo, P., Bjærke, T., Johansen, H. \& Elverhøi, A. 1991a: The Janusfjellet Subgroup (Bathonian to Hauterivian) on Central Spitsbergen; a revised lithostratigraphy. Polar Research 9, 21-43.

Dypvik, H., Nagy, J., Eikeland, T. A., Backer-Owe, K. \& Johansen, H. 1991b: The Bathonian to Hauterivian Janusfjellet Subgroup in Spitsbergen-Depositional conditions as reflected in field appearance and sediment composition. Sedimentary Geology 72, 55-78.

Glazunova, A. E., Blakhmatova, V. T., Lipman, R. K., Romanova, V. J. \& Khokholova, J. A. 1960: Stratigraphy and fauna of Cretaceous deposits of the West-Siberian Lowland. Trudy Nauchno-issledovatelskovo Geologorazvedochnovo Instituta (VSEGEI) 29, 1-347 (Russian).

Laursen, I. 1991: Sekvensstratigrafi i Pliensbach-sen Hauteriv avsetninger i Barentshavet sammenliknet med Svalbard. Cand. scient thesis. Univ. of Oslo. $208 \mathrm{pp}$.

Nagy, J., Løfaldli, M. \& Bäckstrőm, S. A. 1988: Aspects of foraminiferal distribution and depositional conditions in Middle Jurassic to Early Cretaceous shales in eastern Spitsbergen. Pp. 287-300 in Røgl, F. \& Gradstein, F. M. (eds.):
Second Workshop on Agglutinated Foraminifera Vienna 1986, Proceedings. Abhandlungen der Geologischen Bundesanstalt, Wien.

Nagy, J., Pilskog, B. \& Wilhelmsen, R. M. 1990a: Facies controlled distribution of foraminifera in the Jurassic North Sea Basin. Pp. 621-657 in Hemleben, C., Kaminski, M. A., Khunt, W. \& Scott, D. B. (eds.): Paleoecology, Biostratigraphy, Paleoceanography and Taxonomy of Aggluminated Foraminifera. Kluwer Academic Publishers, The Netherlands.

Nagy, J., Løfaldli, M., Bäckström, S. A. \& Johansen, H. 1990b: Agglutinated foraminiferal stratigraphy of Middle Jurassic to basal Cretaceous shales, central Spitsbergen. Pp. 969-1015 in Hemleben, C., Kaminski, M. A., Khunt, W. \& Scott, D. B. (eds.): Paleoecology Biostratigraphy, Paleoceanography and Taxonomy of Agglutinated Foraminifera. Kluwer Academic Publishers, The Netherlands.

Parker, J. R. 1967: The Jurassic and Cretaceous sequence in Spitsbergen. Geological Magazine 104, 487-505.

Saks, V. N. (ed.) 1972: The Jurassic-Cretaceous boundary and the Berriasian Stage in the Boreal Realm. Israel Program for Scientific Translations, 1975, Jerusalem, 1-391.

Sharovskaya, N. V. 1968: Foraminiferal complexes from Jurassic and Lower Cretaceous deposits of the Ust-Yenisei and Turukhan-Yermak Regions. Uchenye Zapiski Nauchnoissledovatelskij Insitut Geologii Arktiki (NIIGA). Paleontologiya i Biostratigrafiya 23, 106-117 (Russian).

Århus, N., Kelly, S. R. A., Collins, J. S. H. \& Sandy, M. R. 1990; Systematic paleontology and biostratigraphy of two Early Cretaceous condenised sections from the Barents Sea. Polar Research 8, 165-194. 